\title{
Vitamin D Status Modulates Inflammatory Response in HIV+ Subjects: Evidence for Involvement of Autophagy and TG2 Expression in PBMC
}

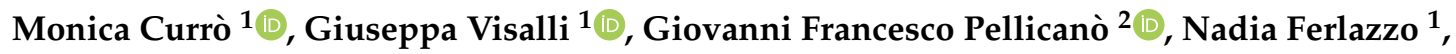 \\ Maria Giovanna Costanzo ${ }^{1}$, Flavia D'Andrea ${ }^{3}$, Daniela Caccamo ${ }^{1}{ }^{\circledR}$, Giuseppe Nunnari ${ }^{3}$ and \\ Riccardo Ientile ${ }^{1, *}$ \\ 1 Department of Biomedical and Dental Sciences and Morphofunctional Imaging, University of Messina, \\ 98125 Messina, Italy; moncurro@unime.it (M.C.); gvisalli@unime.it (G.V.); nferlazzo@unime.it (N.F.); \\ mgc90@hotmail.it (M.G.C.); dcaccamo@unime.it (D.C.) \\ 2 Unit of Infectious Diseases, Department of Human Pathology of Adult and Childhood "Gaetano Barresi", \\ University of Messina, 98125 Messina, Italy; gpellicano@unime.it \\ 3 Unit of Infectious Diseases, Department of Clinical and Experimental Medicine, University of Messina, \\ 98125 Messina, Italy; flavia.dandrea91@libero.it (F.D.); gnunnari@unime.it (G.N.) \\ * Correspondence: ientile@unime.it; Tel.: +39-090-2213383
}

Received: 16 September 2020; Accepted: 11 October 2020; Published: 13 October 2020

check for updates

\begin{abstract}
Conflicting results on the involvement of vitamin D deficiency in inflammatory and immune response in HIV+ subjects are reported. We aimed to characterize the possible influence of vitamin D status on changes in expression of tissue transglutaminase gene (TGM2) and other genes involved in inflammatory response and autophagy in peripheral blood mononuclear cells (PBMC) from HIV+ subjects. HIV+ subjects $(n=57)$ under antiretroviral therapy (ART) and healthy controls $(n=40)$ were enrolled. mRNA levels of 1-alpha-hydroxylase (CYP27B1), tumor necrosis factor- $\alpha$ (TNF- $\alpha)$, interferon- $\gamma($ IFN- $\gamma), T G M 2$, microtubule-associated protein 1A/1B-light chain 3 (LC3), autophagy-related 5 homolog (ATG5), and Beclin 1 (BECN1) were quantified by real-time PCR. In HIV+ subjects, $25(\mathrm{OH}) \mathrm{D}_{3}$ plasma levels were negatively correlated with time since HIV diagnosis. In PBMC from HIV+ subjects, increases in gene expression of TNF- $\alpha$ and IFN- $\gamma$ in comparison to controls were observed. The highest increase in TNF- $\alpha$ transcripts was observed in HIV+ subjects with deficient $25(\mathrm{OH}) \mathrm{D}_{3}$ levels. Autophagy-related genes LC3, ATG5, and BECN1 were down-regulated in HIV+ subjects. Moreover, TGM2 transcripts were up-regulated in PBMC from HIV+ subjects with 25(OH)D3 deficiency. Changes observed in PBMC from HIV+ subjects appeared to be dependent on vitamin D status. The present results suggest that vitamin D deficiency is associated with changes in the expression of markers of inflammation and autophagy, resulting in immune cell dysfunction.
\end{abstract}

Keywords: autophagy; cytokines; HIV; inflammation; peripheral blood mononuclear cells; tissue transglutaminase; vitamin D

\section{Introduction}

Numerous clinical observations show that vitamin D deficiency may be associated with HIV infection [1-3]. Vitamin D status may also be related to side effects of antiretroviral therapy (ART) or other conditions associated with HIV infection [4-9]. An association between low vitamin D levels and increases in markers of inflammation including interleukin-6 (IL-6) and high-sensitivity C-reactive protein (hs-CRP) $[10,11]$ has been reported, while higher vitamin D levels were independently associated with a lower risk of mortality and AIDS events [12]. 
The vitamin D active form, namely, $1,25(\mathrm{OH})_{2} \mathrm{D}_{3}$ is produced in the kidney and also in extrarenal sites, including immune cells, thanks to the presence of enzyme 1-alpha-hydroxylase (CYP27B1) [13,14]. Thus, vitamin D may be linked to autocrine and paracrine regulatory mechanisms, largely described in immune cells $[13,14]$. In recent years, the presence of receptors for 1,25-dihydroxyvitamin D3 $\left[1,25(\mathrm{OH})_{2} \mathrm{D}_{3}\right]$ has been recognized in many cell types, including peripheral blood mononuclear cells (PBMC), with a relevant role in inflammatory response. Consequently, the growing importance of the role of $1,25(\mathrm{OH})_{2} \mathrm{D}_{3}$ in both innate and adaptive immune responses has been highlighted [15].

Decreases in $\mathrm{CD} 4+\mathrm{T}$ lymphocytes were shown as the most relevant change in monitoring pathological conditions associated with HIV [16,17]. Although programmed cell death through apoptosis has been the most commonly described mechanism for lymphocyte depletion, more recent results give evidence of the occurrence of dysfunctional autophagy, which can be associated with both innate and adaptive immunity. It has been shown that HIV infection, leading to autophagy down-regulation in peripheral blood mononuclear cells (PBMC), can be related to mechanisms that permit viral replication but also allow sufficient autophagy for cell survival [18-20].

Autophagy plays a critical role in the homeostasis of inflammatory cells, such as macrophages, neutrophils, and lymphocytes, which may also be modulated by non-classical effects of vitamin $\mathrm{D}$ [21]. It has been demonstrated that adequate concentrations of $1,25(\mathrm{OH})_{2} \mathrm{D}_{3}$, inhibit Mycobacterium tuberculosis and HIV replication in coinfected macrophages through autophagy activation. In particular, the involvement of autophagy has been demonstrated by inhibiting the genes coding for Beclin 1 (BECN1) and autophagy-related 5 homolog (ATG5), two proteins specifically required for autophagy [22].

A large amount of data have underlined the fact that inflammatory reactions are early events leading to cell responses by which HIV infection increases the risk of various pathological conditions. Tissue transglutaminase (TG2), an ubiquitous member of the transglutaminase enzyme family, has been proposed as an early marker of inflammatory response activation [23-26]. Particular emphasis has been given to the induction of TGM2, the gene coding for TG2, in immune system cells for monitoring disease progression in HIV-infected individuals [27]. Recently, in healthy subjects with vitamin D deficiency, we gave evidence of a concomitant increase in mRNA levels of TGM2 and pro-inflammatory cytokines, as well as biomarkers of cell adhesion, such as intercellular adhesion molecule 1 (ICAM) and lymphocyte function-associated antigen 1 (LFA-1), involved in immune activation, indicating that TG2 may be a marker of PBMC activation [24,28]. While there are many studies on the relationship between HIV infection and vitamin D status, there are few results to emphasize the relation between vitamin D and inflammatory response associated with HIV in PBMC. The purpose of our study was to characterize the possible influence of vitamin D status on changes in the expression of TGM2 and other genes, involved in inflammatory response and autophagy, in PBMC from HIV+ subjects.

\section{Results}

A total of $57 \mathrm{HIV}+$ subjects (mean age: $43.2 \pm 1.8 ; 34$ males and 23 females) under ART for at least 1 year were enrolled in this study. The main characteristics are given in Table 1 . In parallel, 40 healthy subjects that were age- and sex-matched (mean age: $41.5 \pm 1.6 ; 24$ males and 16 females) were included in the control cohort.

Table 1. Main clinical characteristics of the $57 \mathrm{HIV}+$ subjects included in the cohort.

\begin{tabular}{cc}
\hline Characteristic & Mean \pm SEM \\
\hline Age & $43.2 \pm 1.8$ \\
\hline Sex (female/male) & $23 / 34$ \\
\hline Time since HIV diagnosis (months) & $93.1 \pm 10.1$ \\
\hline HIV viral load (copies/mL) & $41.3 \pm 26.4$ \\
\hline
\end{tabular}

SEM: standard error of the mean. 
In HIV+ subjects, the plasma concentrations of 25-hydroxyvitamin D3 $\left[25(\mathrm{OH}) \mathrm{D}_{3}\right]$ were $59.9 \pm 3.6 \mathrm{nmol} / \mathrm{L}$, which were lower than the normal reference range $(75-200 \mathrm{nmol} / \mathrm{L})$ and significantly lower than those in healthy subjects $(87.4 \pm 4.9 \mathrm{nmol} / \mathrm{L}, p<0.001)$.

According to previous studies [28-30], HIV + subjects included in our study were divided into three groups as follows: $25(\mathrm{OH}) \mathrm{D}_{3}$ deficiency $(\leq 50 \mathrm{nmol} / \mathrm{L})$, insufficiency $(51-74 \mathrm{nmol} / \mathrm{L})$, and sufficiency ( $\geq 75 \mathrm{nmol} / \mathrm{L}$ ).

In particular, among the HIV+ subjects, only 15 had sufficient $25(\mathrm{OH}) \mathrm{D}_{3}$ plasma levels $(96.9 \pm 3.7 \mathrm{nmol} / \mathrm{L})$, while 17 subjects had insufficient $(63.4 \pm 1.3 \mathrm{nmol} / \mathrm{L})$ and 25 subjects deficient $(35.4 \pm 1.8 \mathrm{nmol} / \mathrm{L}) 25(\mathrm{OH}) \mathrm{D}_{3}$ plasma levels. Instead, most of the controls $(n=25)$ had sufficient $25(\mathrm{OH}) \mathrm{D}_{3}$ levels $(106.4 \pm 4.2 \mathrm{nmol} / \mathrm{L})$, while only nine and six healthy subjects had insufficient $(65.8 \pm 2 \mathrm{nmol} / \mathrm{L})$ and deficient $(40.6 \pm 3.4 \mathrm{nmol} / \mathrm{L}) 25(\mathrm{OH}) \mathrm{D}_{3}$ levels, respectively.

As reported in Figure 1, the $25(\mathrm{OH}) \mathrm{D}_{3}$ depletion was associated with HIV infection. Indeed, plasma concentrations of $25(\mathrm{OH}) \mathrm{D}_{3}$ in HIV + subjects were negatively correlated with time since HIV diagnosis $(r=-0.386, p=0.003)$.

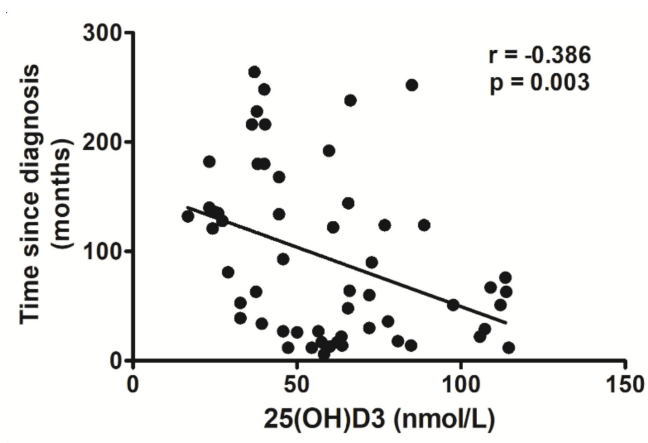

Figure 1. Correlation analysis between $25(\mathrm{OH}) \mathrm{D}_{3}$ plasma levels and time since HIV diagnosis.

Multiple linear regression analysis, including age as an independent variable, demonstrated that $25(\mathrm{OH}) \mathrm{D}_{3}$ concentrations were dependent on time elapsed from HIV diagnosis (standardized coefficient beta $=-0.441,95 \% \mathrm{CI}:-0.761$ to $-0.121, p=0.008$ ), but independent of patient's age (standardized coefficient beta $=-0.09,95 \%$ CI: -0.230 to $0.410, p=0.576$ ).

To ascertain possible changes in cell signaling associated with different vitamin D status in HIV+ subjects, we evaluated mRNA transcripts of genes involved in vitamin D activation, inflammation, and autophagy in PBMC from HIV+ subjects as well as healthy subjects.

Notably, we found decreased CYP27B1 mRNA levels in HIV+ subjects compared with healthy subjects. Even in HIV+ subjects with vitamin D sufficiency, we observed a significant downregulation of the CYP27B1 gene transcription in comparison to healthy subjects with vitamin D sufficient status (Figure 2).

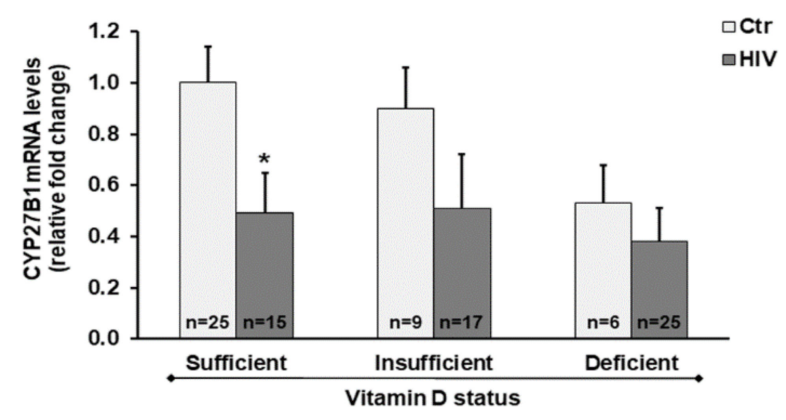

Figure 2. CYP27B1 expression in peripheral blood mononuclear cells (PBMC) from HIV+ and healthy subjects. mRNA transcript levels were evaluated by real-time PCR. The results are expressed as mean \pm SEM. ${ }^{*} p<0.05$ significant difference in comparison to healthy subjects with sufficient $25(\mathrm{OH}) \mathrm{D}_{3}$ levels. 
As reported in Figure 3, we provide evidence for the influence of vitamin D status on changes in expression of pro-inflammatory mediators. In PBMC from HIV+ subjects, we observed a significant increase in gene expression of both tumor necrosis factor- $\alpha$ (TNF- $\alpha)$ and interferon- $\gamma($ IFN- $\gamma)$ when compared with PBMC from control subjects. Of note, the most relevant increase in mRNA transcripts of TNF- $\alpha$ was observed in HIV+ subjects with deficient $25(\mathrm{OH}) \mathrm{D}_{3}$ levels.
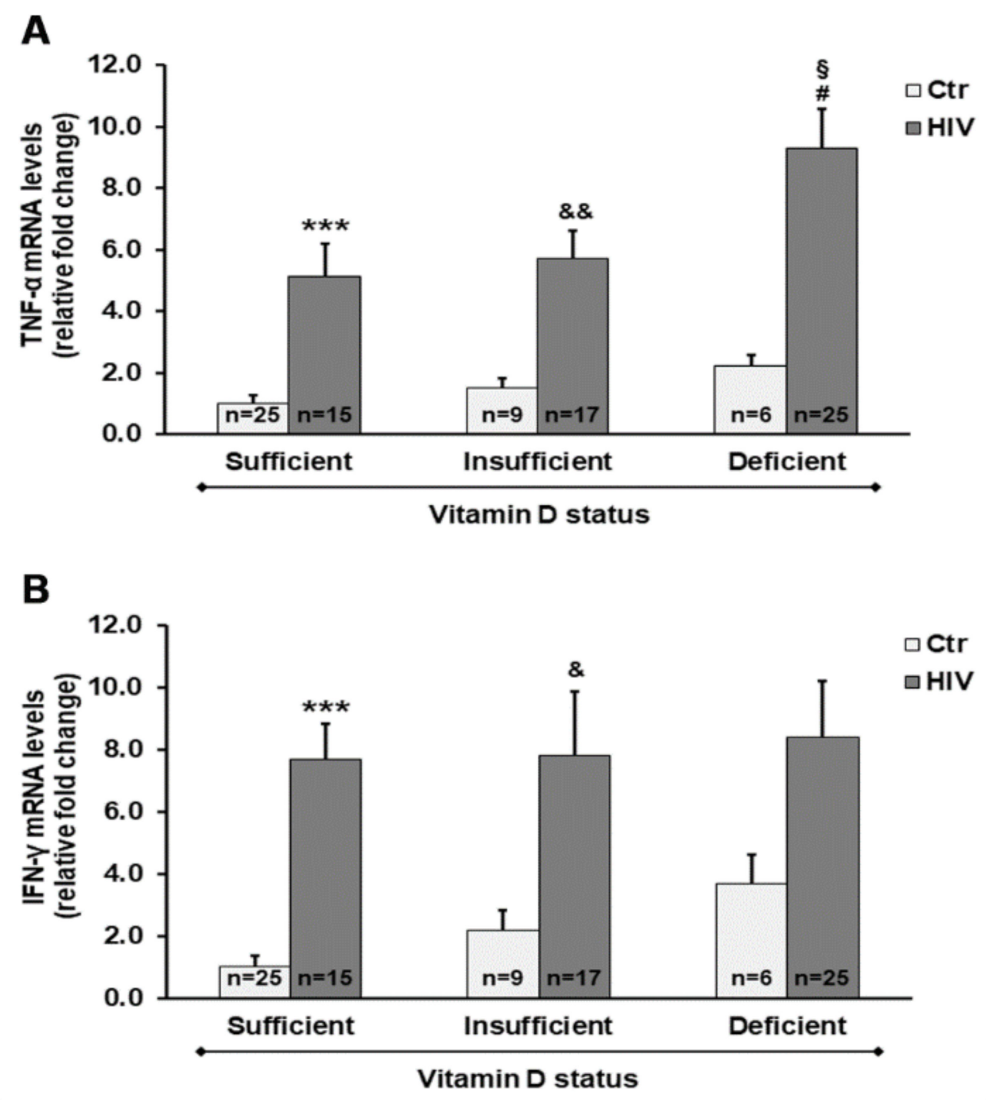

Figure 3. Gene expression of both tumor necrosis factor- $\alpha$ (TNF- $\alpha)(\mathbf{A})$ and interferon- $\gamma(I F N-\gamma)(\mathbf{B})$ in PBMC from HIV+ and healthy subjects. mRNA transcript levels were evaluated by real-time PCR. The results are expressed as mean \pm SEM. ${ }^{* * *} p<0.001$ significant differences in comparison to healthy subjects with sufficient $25(\mathrm{OH}) \mathrm{D}_{3}$ levels; ${ }^{\&} p<0.05$ and $\& \& p<0.01$ significant differences in comparison to healthy subjects with insufficient $25(\mathrm{OH}) \mathrm{D}_{3}$ levels; $\# p<0.05$ significant differences in comparison to healthy subjects with deficient $25(\mathrm{OH}) \mathrm{D}_{3}$ levels; ${ }^{\S} p<0.05$ significant difference in comparison to HIV+ subjects with sufficient $25(\mathrm{OH}) \mathrm{D}_{3}$ levels.

We also assessed the mRNA transcript levels of different autophagy-related genes and TGM2 in PBMC from $\mathrm{HIV}+$ subjects with different $25(\mathrm{OH}) \mathrm{D}_{3}$ levels.

Overall, the microtubule-associated protein 1A/1B-light chain 3 (LC3), ATG5, and BECN1 genes were downregulated in HIV+ subjects compared with healthy subjects. A highly significant downregulation of $A T G 5$ was observed in HIV+ subjects with either a deficient or insufficient vitamin D status, compared with controls. In addition, $L C 3$ and BECN1 mRNA transcript levels were significantly reduced in $\mathrm{HIV}+$ subjects with $25(\mathrm{OH}) \mathrm{D}_{3}$ deficiency, and were also reduced by about $40 \%(p>0.05)$ in subjects with $25(\mathrm{OH}) \mathrm{D}_{3}$ insufficiency compared with healthy subjects (Figure 4 ). 

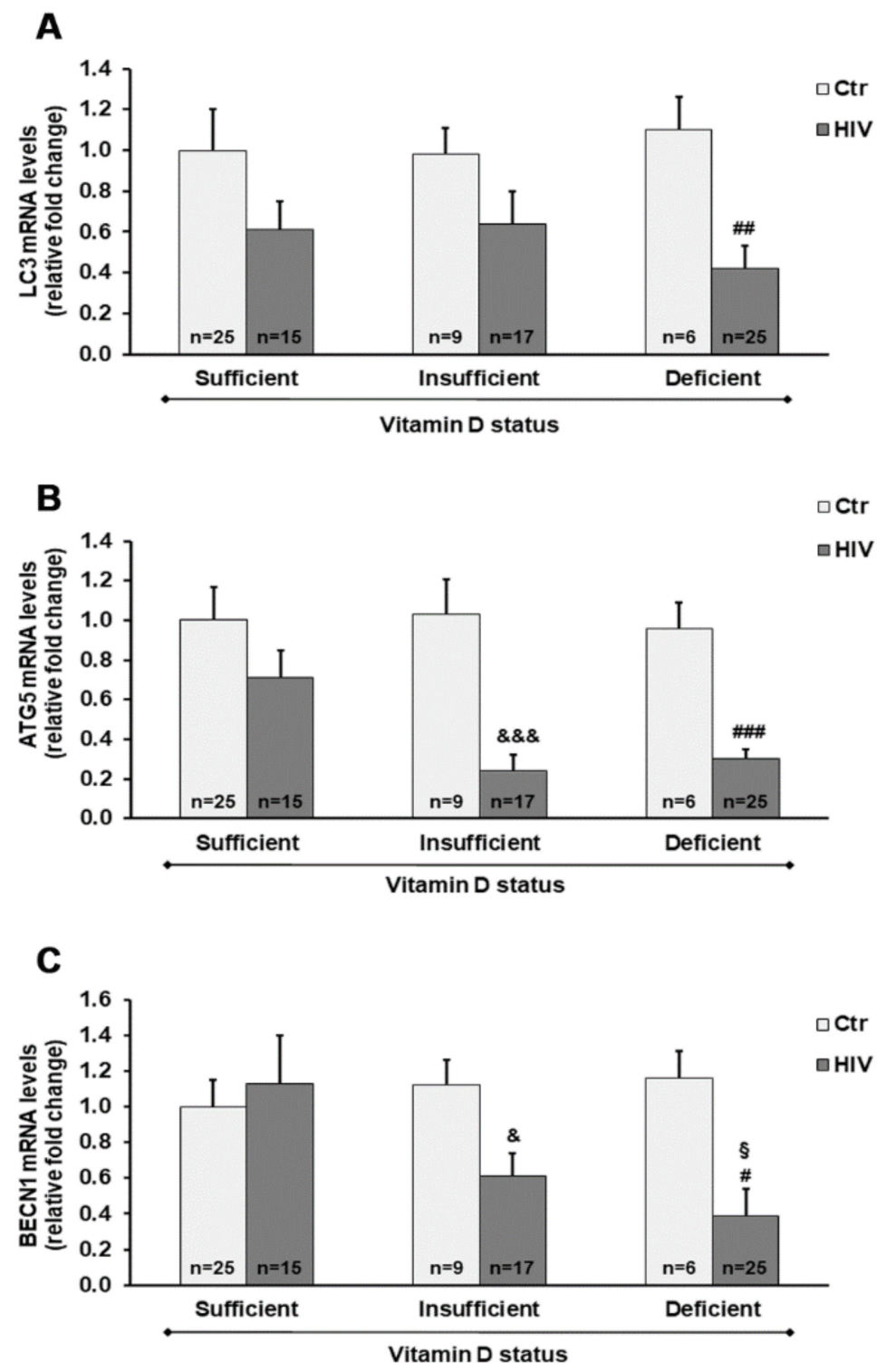

Figure 4. Gene expression of microtubule-associated protein 1A/1B-light chain 3 (LC3) (A), autophagy-related 5 homolog (ATG5) (B), and Beclin 1 (BECN1) (C) in PBMC from HIV+ and healthy subjects. mRNA transcript levels were evaluated by real-time PCR. The results are expressed as mean \pm SEM. ${ }^{\&} p<0.05$ and $\& \& \& p<0.001$ significant differences in comparison to healthy subjects with insufficient $25(\mathrm{OH}) \mathrm{D}_{3}$ levels; \# $p<0.05$, \#\# $p<0.01$, and \#\#\# $p<0.001$ significant differences in comparison to healthy subjects with deficient $25(\mathrm{OH}) \mathrm{D}_{3}$ levels; $\S p<0.05$ significant difference in comparison to $\mathrm{HIV}+$ subjects with sufficient $25(\mathrm{OH}) \mathrm{D}_{3}$ levels.

We also observed a significant up-regulation of TGM2 mRNA transcript levels in HIV+ subjects with $25(\mathrm{OH}) \mathrm{D}_{3}$ deficiency compared with HIV+ subjects with either insufficient or sufficient levels of $25(\mathrm{OH}) \mathrm{D}_{3}$ (Figure $\left.5 \mathrm{~A}\right)$. Analysis of the protein expression confirmed these results, showing an increase of TG2 protein amounts in HIV+ subjects with $25(\mathrm{OH}) \mathrm{D}_{3}$ deficiency (Figure $5 \mathrm{~B}, \mathrm{C}$ ). 

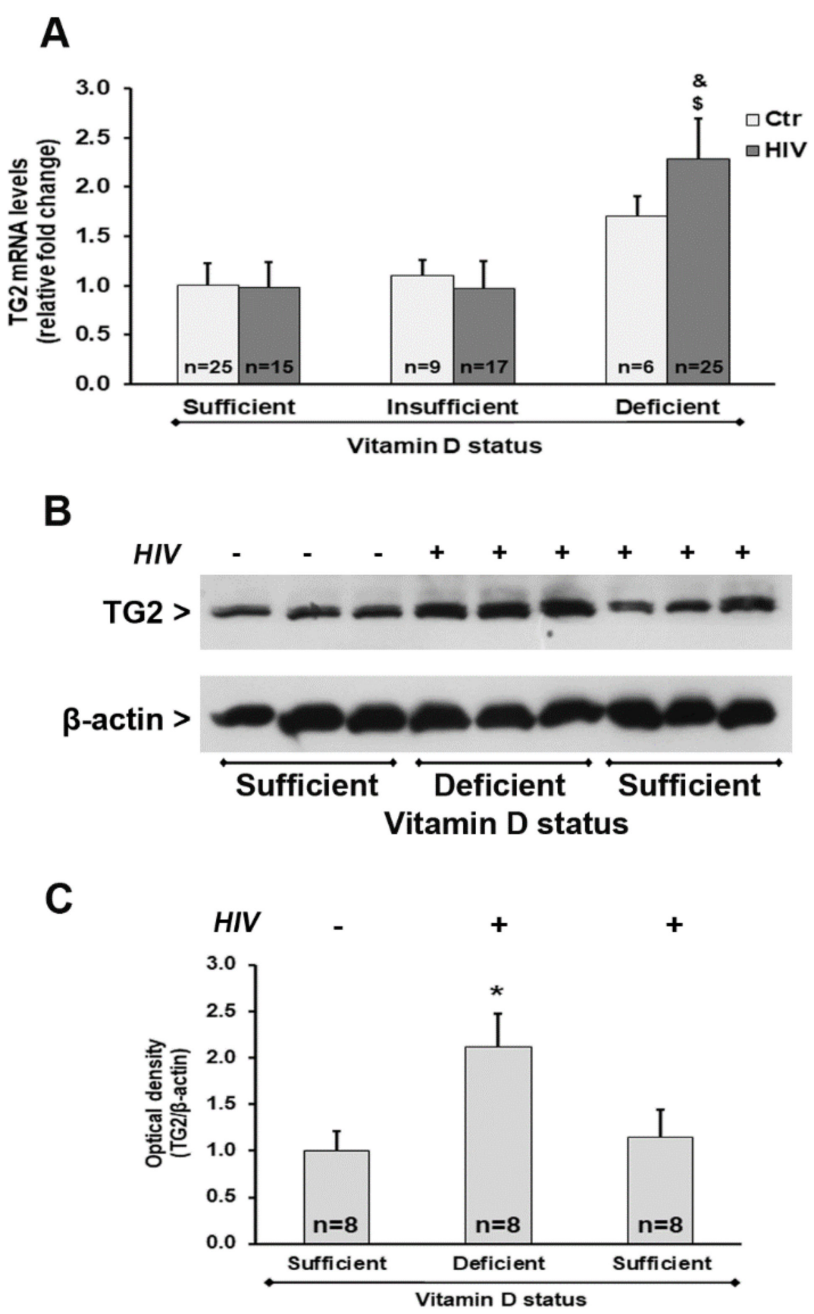

Figure 5. Tissue transglutaminase (TG2) expression in PBMC from HIV+ and healthy subjects. (A) mRNA transcript levels were evaluated by real-time PCR. The results are expressed as mean \pm SEM. (B) Western blot analysis of TG2. (C) Densitometric analysis of immunoblots. The results are representative of the values (mean $\pm \mathrm{SEM}$ ) obtained from eight subjects for each group. ${ }^{*} p<0.05$ significant difference in comparison to healthy subjects with sufficient $25(\mathrm{OH}) \mathrm{D}_{3}$ levels; ${ }^{\$} p<0.05$ significant difference in comparison to $\mathrm{HIV}+$ subjects with sufficient $25(\mathrm{OH}) \mathrm{D}_{3}$ levels; \& $p<0.05$ significant difference in comparison to $\mathrm{HIV}+$ subjects with insufficient $25(\mathrm{OH}) \mathrm{D}_{3}$ levels.

Finally, as shown by the results of the generalized linear model (GLM), all genes (except BECN1) were significantly influenced by at least one of the predictors included in the model. In particular, expression of TNF- $\alpha$, IFN- $\gamma$, and ATG5 genes was dependent on HIV positivity and $25(\mathrm{OH}) \mathrm{D}_{3}$ levels. CYP27B1 gene expression was significantly dependent on HIV infection, and a near significant dependence on $25(\mathrm{OH}) \mathrm{D}_{3}(p=0.072)$ was also observed. LC3 gene expression was only influenced by HIV infection, and TGM2 was only influenced by $25(\mathrm{OH}) \mathrm{D}_{3}$ levels (Table 2$)$. 
Table 2. Generalized linear model (GLM) for gene expression, accounting for the influence of HIV infection, $25(\mathrm{OH}) \mathrm{D}_{3}$ levels, gender, age, and time since HIV diagnosis.

\begin{tabular}{|c|c|c|c|}
\hline \multirow[b]{2}{*}{ Variables } & \multicolumn{3}{|c|}{$C Y P 27 B 1$ Gene Expression } \\
\hline & B & 95\% C.I. & $p$-Value \\
\hline HIV infection & -0.301 & $-0.4932 ;-0.110$ & 0.002 \\
\hline Gender & 0.116 & $-0.022 ; 0.254$ & 0.098 \\
\hline Age & 0.001 & $-0.007 ; 0.006$ & 0.899 \\
\hline 25(OH)D3 levels & 0.002 & $0.000 ; 0.005$ & 0.072 \\
\hline \multirow[t]{2}{*}{ Time since HIV diagnosis \# } & 0.001 & $-0.001 ; 0.002$ & 0.283 \\
\hline & \multicolumn{3}{|c|}{ TNF- $\alpha$ gene expression } \\
\hline HIV infection & 0.622 & $0.403 ; 0.842$ & 0.000 \\
\hline Gender & 0.075 & $-0.084 ; 0.233$ & 0.355 \\
\hline Age & 0.004 & $-0.003 ; 0.011$ & 0.279 \\
\hline 25(OH)D3 levels & -0.003 & $-0.006 ;-0.001$ & 0.022 \\
\hline \multirow[t]{2}{*}{ Time since HIV diagnosis \# } & 0.001 & $-0.001 ; 0.002$ & 0.546 \\
\hline & \multicolumn{3}{|c|}{ IFN- $\gamma$ gene expression } \\
\hline HIV infection & 0.606 & $0.313 ; 0.900$ & 0.000 \\
\hline Gender & 0.040 & $-0.171 ; 0.252$ & 0.709 \\
\hline Age & -0.006 & $-0.016 ; 0.003$ & 0.210 \\
\hline 25(OH)D3 levels & -0.005 & $-0.008 ;-0.001$ & 0.018 \\
\hline \multirow[t]{2}{*}{ Time since HIV diagnosis \# } & -0.002 & $-0.005 ; 0.002$ & 0.983 \\
\hline & \multicolumn{3}{|c|}{$L C 3$ gene expression } \\
\hline HIV infection & -0.280 & $-0.499 ;-0.060$ & 0.012 \\
\hline Gender & -0.024 & $-0.182 ; 0.134$ & 0.763 \\
\hline Age & 0.001 & $-0.006 ; 0.008$ & 0.745 \\
\hline 25(OH)D3 levels & 0.002 & $-0.001 ; 0.005$ & 0.176 \\
\hline \multirow[t]{2}{*}{ Time since HIV diagnosis \# } & 0.001 & $-0.001 ; 0.002$ & 0.477 \\
\hline & \multicolumn{3}{|c|}{ ATG5 gene expression } \\
\hline HIV infection & -0.334 & $-0.525 ;-0.143$ & 0.001 \\
\hline Gender & 0.086 & $-0.051 ; 0.224$ & 0.218 \\
\hline Age & 0.005 & $-0.001 ; 0.011$ & 0.105 \\
\hline 25(OH)D3 levels & 0.003 & $0.001 ; 0.005$ & 0.019 \\
\hline \multirow[t]{2}{*}{ Time since HIV diagnosis \# } & -0.001 & $-0.003 ; 0.001$ & 0.729 \\
\hline & \multicolumn{3}{|c|}{$B E C N 1$ gene expression } \\
\hline HIV infection & -0.168 & $-0.451 ; 0.0115$ & 0.245 \\
\hline Gender & -0.092 & $-0.296 ; 0.113$ & 0.379 \\
\hline Age & 0.006 & $-0.003 ; 0.016$ & 0.178 \\
\hline 25(OH)D3 levels & 0.002 & $-0.001 ; 0.006$ & 0.263 \\
\hline \multirow[t]{2}{*}{ Time since HIV diagnosis \# } & -0.001 & $-0.002 ; 0.002$ & 0.874 \\
\hline & \multicolumn{3}{|c|}{ TGM2 gene expression } \\
\hline HIV infection & 0.025 & $-0.158 ; 0.209$ & 0.787 \\
\hline Gender & -0.007 & $-0.139 ; 0.125$ & 0.916 \\
\hline Age & 0.002 & $-0.004 ; 0.008$ & 0.490 \\
\hline 25(OH)D3 levels & -0.003 & $-0.006 ;-0.001$ & 0.005 \\
\hline Time since HIV diagnosis \# & -0.002 & $-0.003 ; 0.001$ & 0.925 \\
\hline
\end{tabular}

Bold font for $p$-values indicates statistically significant differences at a level $\leq 0.05$. \# This variable has only been tested on HIV+ subjects. 


\section{Discussion}

A decrease in vitamin D levels is frequently reported during HIV infection, and vitamin D supplementation is frequently used in the clinical treatment of HIV+ subjects. Besides numerous observations emphasizing the regulation of calcium/phosphate homeostasis, the involvement of vitamin D status in immune response is widely evident. Furthermore, HIV+ subjects with vitamin D receptor variants showed a significantly increased risk of progression to AIDS [31,32].

Present results also give evidence for an important relationship between vitamin $\mathrm{D}$ and disease progression. In our cohort of HIV+ subjects, we observed a negative correlation between $25(\mathrm{OH}) \mathrm{D}_{3}$ levels and time since HIV diagnosis. The low levels of $25(\mathrm{OH}) \mathrm{D}_{3}$ may be related to increased production of proinflammatory cytokines, such as TNF- $\alpha$ and IFN- $\gamma$, which in turn inhibit the effects of parathyroid hormone $(\mathrm{PTH})$ and the hydroxylation of calcidiol $\left[25(\mathrm{OH}) \mathrm{D}_{3}\right]$ in the kidney, preventing the synthesis of active calcitriol $\left[1,25(\mathrm{OH})_{2} \mathrm{D}_{3}\right][33,34]$. Additionally, ART has been reported to influence vitamin $\mathrm{D}$ status in HIV+ subjects [35].

Further observations on different cell responses may be useful to define other approaches based on vitamin D supplementation for therapy and monitoring of HIV-associated pathological conditions. In this study, we found a decrease in mRNA transcript of CYP27B1 gene in PBMC of HIV+ subjects. Thus, it is possible to hypothesize that the reduced expression of CYP27B1 in PBMC could lead to low availability of $1,25(\mathrm{OH})_{2} \mathrm{D}_{3}$ in cells, promoting a proinflammatory phenotype. Changes in CYP27B1 mRNA transcript levels potentially confirm the association between vitamin D deficiency and immune diseases. A previous study demonstrated that, in response to LPS stimulation, placentas from CYP27B1 knockout mice expressed higher level of cytokines, chemokines, and chemokine receptors than $C Y P 27 B 1^{+/+}$placentas, highlighting the role for $C Y P 27 B 1$ in the control of response to inflammatory stimuli [36]. Furthermore, in PBMC of healthy control subjects, the expression of the CYP27B1 gene is dependent on a linkage disequilibrium block on chromosome 12, associated with several autoimmune diseases, as well as reduced expression of CYP27B1 risk allele in tolerizing dendritic cells, which is consistent with reduced vitamin $D$ function contributing to autoimmune disease risk [37]. Given that the CYP27B1 enzyme exerts a critical role for cell specific functions, the potential to modulate $1,25(\mathrm{OH})_{2} \mathrm{D}_{3}$ production in specific tissues may improve the treatment of immune diseases [38].

In the present study, we also aimed to characterize the relationship between $25(\mathrm{OH}) \mathrm{D}_{3}$ plasma levels and inflammatory response of PBMC, which may be useful to study the underlying molecular mechanisms associated with endocrine, paracrine, and autocrine responses that are dependent on cholecalciferol metabolism and vitamin D status. We found that vitamin D levels affect the expression of TNF- $\alpha$ and IFN- $\gamma$ in PBMC. These observations can largely be used to characterize the expression of relevant markers of cell modifications such as those responsible for inflammatory process.

An increase in the expression of cytokines, chemokines, and interleukins has been shown in HIV+ subjects, as well as in numerous inflammatory processes [39]. Increases of inflammatory mediators and activated monocyte phenotypes associated with vitamin D deficiency $[40,41]$ have been related to tissue dysfunction, comorbidity development, AIDS progression, and death in HIV-infected people [42,43].

As recently reported, the mechanisms associated with HIV disease progression and the process of autophagy may play an essential role in acute and chronic inflammatory processes. Although the involvement of autophagy in different cell types from HIV+ subjects must be better clarified, recent evidence suggests that autophagy-mediated mechanisms may potentiate the recognition and degradation of the newly synthesized viral particles in immune infected cells. HIV infection leads to autophagy inhibition to prevent lysosomal degradation of HIV proteins, and thus several studies have indicated the potentially beneficial effects of pro-autophagy drugs to enhance the control of HIV infection [20]. On the basis of the present results, it is possible to suggest that vitamin D status can affect the expression of different autophagy markers. Indeed, LC3, ATG5, and BECN1 were expressed at lower levels in PBMC from HIV+ subjects with $25(\mathrm{OH}) \mathrm{D}_{3}$ deficiency compared with HIV+ subjects with adequate $25(\mathrm{OH}) \mathrm{D}_{3}$ levels, and the $A T G 5$ gene expression was significantly dependent 
on $25(\mathrm{OH}) \mathrm{D}_{3}$ levels. The down-regulation of autophagy-related genes was associated with an increase of TNF- $\alpha$ and IFN- $\gamma$ mRNA levels, also suggesting that autophagy may be involved in the control of cytokine production. As previously shown, several mechanisms underlying the modulatory effects of vitamin D on autophagy signaling have been demonstrated [44], i.e., vitamin D down-regulates expression and inhibits the activity of mammalian target of rapamycin (mTOR), a negative regulator of autophagy [45]. Moreover, cathelicidin, an essential protein in autophagosome formation, is a vitamin $\mathrm{D}$ receptor (VDR) target gene. Accordingly, vitamin D enhances Beclin 1 expression and autophagy through the up-regulation of cathelicidin [45].

We also first demonstrated that the decreased expression in biomarkers of autophagy was associated with elevated expression of TGM2, and that $25(\mathrm{OH}) \mathrm{D}_{3}$ levels represented a good predictor of TGM2 transcription. TG2 is a well-known player in inflammatory conditions. During inflammation, monocytes are recruited into tissues and differentiated into macrophages [46]. Other results showed TG2 expression is highly up-regulated in monocytes during adhesion onto endothelial cells, indicating that TG2 is required for monocyte extravasation [47]. TG2 can mediate phagocytosis of apoptotic cells, a crucial process for resolution of inflammation and prevention of autoimmune disease development [25]. We previously reported the up-regulation of TGM2 in PBMC in $25(\mathrm{OH}) \mathrm{D}_{3}$-deficient subjects. Furthermore, a significant positive correlation between TGM2 expression and TNF- $\alpha$ mRNA levels was evident [24]. Similarly, the present results demonstrated a concurrent increase in TGM2 and TNF- $\alpha$ mRNA levels, suggesting a relationship between expression of TGM2 in PBMC and inflammatory response $[24,28]$.

In the present study, however, the possible effects of vitamin D intake were not evaluated. Further studies are needed to determine whether vitamin D supplementation in HIV+ subjects induces changes in basal autophagy and immune response.

To summarize, the present results suggest that in HIV+ subjects, vitamin D deficiency may be associated with changes in expression of TGM2 as well as other markers of inflammation and autophagy, resulting in immune cell dysfunction. The isolation of PBMC may be useful to characterize molecular mechanisms associated with inflammation and autophagy. However, the interaction of autophagy with pathological conditions such as HIV infection should be more deeply investigated.

\section{Materials and Methods}

\subsection{Patient Recruitment}

The study was conducted in accordance with the Declaration of Helsinki, and the protocol was approved by the local ethics committee (University of Messina, protocol number 10-20 28 January 2020). Informed written consent was obtained from all participants.

A total of $57 \mathrm{HIV}+$ subjects who attended the Unit of Infectious Diseases of the Polyclinic Hospital-University of Messina, were recruited for this study. All subjects were treated with ART, integrase strand transfer inhibitor plus 2 nucleoside reverse transcriptase inhibitors, according to recommendations on first-line antiretroviral regimens reported in the national guidelines of 2017, for at least 1 year. Thus, it was not possible to analyze therapeutic impact on examined markers of both inflammation and autophagy. Eligibility criteria required the absence of autoimmune disease, anti-inflammatory medications, and vitamin D supplementation.

The control group consisted of 40 healthy subjects matched for age and gender. Blood samples were collected in ethylenediaminetetraacetic acid (EDTA) tubes from both patients and controls. Plasma was obtained after blood centrifugation and stored at $-20^{\circ} \mathrm{C}$ until analysis.

\subsection{Determination of $25(\mathrm{OH}) \mathrm{D}_{3}$ Plasma Levels}

The quantitative determination of $25(\mathrm{OH}) \mathrm{D}_{3}$ plasma levels was performed by high-performance liquid chromatography (HPLC) with a Bio-Rad $25(\mathrm{OH}) \mathrm{D}_{3} / \mathrm{D} 2$ kit (Bio-Rad, Milan, Italy) according to 
the manufacturer's instructions. Separation of 25-OH-vitamin D3 and internal standard took place on a reversed-phase cartridge followed by subsequent $U V$ detection $(\lambda=265 \mathrm{~nm})$ and quantitative evaluation.

\subsection{PBMC Collection}

PBMC were isolated by centrifugation on a Ficoll Histopaque density gradient. The blood collected in test tubes containing EDTA was diluted at a ratio of 1:2 in phosphate-buffered saline (PBS), layered on $4 \mathrm{~mL}$ of Ficoll, and centrifuged at $400 \times \mathrm{g}$ for $20 \mathrm{~min}$. PBMC, layered in the Ficoll plasma interface, were harvested, washed twice with PBS, and stored at $-80^{\circ} \mathrm{C}$ until use.

\subsection{Quantitative Studies of Gene Expression}

Total RNA isolation from PBMC was carried out using the TRIzol reagent (Invitrogen, Milan, Italy), according to the manufacturer's instructions. Two micrograms of total RNA were reverse-transcribed into complementary DNA (cDNA) by using the High-Capacity cDNA Archive Kit (ThermoFisher Scientific, Milan, Italy). mRNA levels of CYP27B1, TNF- $\alpha$, IFN- $\gamma, T G M 2, L C 3, A T G 5$, and BECN1 were quantified by SYBR green-based real-time PCR. The primer sequences used are listed in Table 3 . Quantitative PCR reactions were carried out in $10 \mu \mathrm{L}$ reactions containing $1 \times$ SYBR green PCR Mastermix, $0.1 \mu \mathrm{M}$ specific primers, and $25 \mathrm{ng}$ RNA converted into cDNA. $\beta$-Actin was used as endogenous control. Real-time PCR was performed in a 7900HT Fast Real-Time PCR System (Applied Biosystems, Foster City, CA, USA) with the following profile: one cycle at $95^{\circ} \mathrm{C}$ for $10 \mathrm{~min}$, followed by 40 cycles at $95^{\circ} \mathrm{C}$ for $15 \mathrm{~s}$ and $60{ }^{\circ} \mathrm{C}$ for $1 \mathrm{~min}$. For SYBR green assays, we added a standard dissociation stage to assess primer specificity. Data were collected with SDS 2.3 software (Applied Biosystems, Foster City, CA, USA) and analyzed using the $2^{-\Delta \Delta C t}$ relative quantification method.

Table 3. Primer sequences used for SYBR green real-time PCR.

\begin{tabular}{ccc}
\hline Gene & Primer & Sequence 5 $^{\prime} \rightarrow 3^{\prime}$ \\
\hline$\beta-A C T$ & forward & TGGTTACAGGAAGTCCCTTGCC \\
\hline$\beta-A C T$ & reverse & ATGCTATCACCTCCCCTGTGTG \\
\hline$C Y P 27 B 1$ & forward & GGAACCCTGAACAACGTAGTC \\
\hline$C Y P 27 B 1$ & reverse & AGTCCGAACTTGTAAAATTCCCC \\
\hline$T G M 2$ & forward & CCTTACGGAGTCCAACCTCA \\
\hline$T G M 2$ & reverse & CCGTCTTCTGCTCCTCAGTC \\
\hline$T N F-\alpha$ & forward & GTGAGGAGGACGAACATC \\
\hline$T N F-\alpha$ & reverse & GAGCCAGAAGAGGTTGAG \\
\hline$I F N-\gamma$ & forward & GCAGCCAACCTAAGCAAGAT \\
\hline$I F N-\gamma$ & reverse & TCACCTGACACATTCAAGTTCTG \\
\hline$L C 3$ & forward & CGGTGATAATAGAACGATACAAG \\
\hline$L C 3$ & reverse & CTGAGATTGGTGTGGAGAC \\
\hline$A T G 5$ & forward & TGCCTGAACAGAATCATCCTT \\
\hline$A T G 5$ & reverse & CCAGCCCAGTTGCCTTAT \\
\hline$B E C N 1$ & forward & ACAGTGAACAGTTACAGATGGA \\
\hline$B E C N 1$ & reverse & CTCAGCCTGGACCTTCTC \\
\hline
\end{tabular}

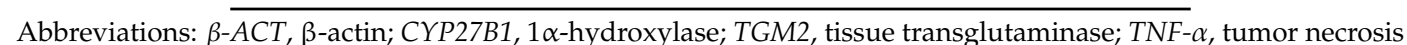
factor- $\alpha$; IFN- $\gamma$, interferon- $\gamma ; L C 3$, microtubule-associated protein 1A/1B-light chain 3; ATG5, autophagy-related 5; BECN1, Beclin 1. 


\subsection{Power and Sample Size Calculation}

A power analysis (ANOVA with fixed effects) was performed to establish the adequate number of subjects to be enrolled considering expression of TNF- $\alpha$ gene as primary outcome. Assuming an effect size of 0.4 , an alpha error probability equal to 0.05 , a power level of 0.8 , and six groups, we found that a number of 90 subjects was necessary to ensure an adequate power. A posteriori, on the basis of different sample sizes within each group, we assessed that the achieved power was equal to 0.85 . The software used for power analysis was $G^{*}$ Power, version 3.1.9.4.

\subsection{Statistical Analysis}

All values are expressed as mean \pm standard error of the mean (SEM). Since all examined variables were normally distributed, as verified by the Kolmogorov-Smirnov test, we performed analyses by parametric tests. Comparisons between two groups were performed by Student's $t$-test. Comparisons between more groups were carried out using one-way ANOVA followed by Bonferroni's post-hoc test. To evaluate the relationship between two variables, we applied Pearson's correlation analysis. The multiple linear regression test was used to assess the dependence of $25(\mathrm{OH}) \mathrm{D}_{3}$ plasma concentrations on time since diagnosis and age. Generalized linear models (GLM) were estimated for the expression of each gene in order to account for the influence of HIV infection and vitamin D levels, inserting potential confounders such as age; gender; and, only for HIV+ subjects, time since HIV diagnosis. Statistical analyses were performed using SPSS v22. Differences were considered significant for values of $p<0.05$.

Author Contributions: Conceptualization, G.F.P. and R.I; investigation, M.G.C.; supervision, M.C.; validation, N.F. and M.C.; formal analysis, F.D.; data curation, G.V.; writing — Original draft preparation, R.I.; writing — Review and editing, D.C.; resources, G.N.; project administration, R.I. All authors have read and agreed to the published version of the manuscript.

Funding: This research received no external funding.

Acknowledgments: This work was supported by departmental funding. The authors thank Isa Picerno for her valuable comments that greatly improved the manuscript. The authors would like to thank Angela Alibrandi for her valuable assistance with the statistical analyses.

Conflicts of Interest: The authors declare no conflict of interest.

\section{References}

1. Mueller, N.J.; Fux, C.A.; Ledergerber, B.; Elzi, L.; Schmid, P.; Dang, T.; Magenta, L.; Calmy, A.; Vergopoulos, A.; Bischoff-Ferrari, H.A.; et al. High prevalence of severe vitamin D deficiency in combined antiretroviral therapy-naive and successfully treated Swiss HIV patients. AIDS 2010, 24, 1127-1134. [CrossRef] [PubMed]

2. Vescini, F.; Cozzi-Lepri, A.; Borderi, M.; Re, M.C.; Maggiolo, F.; De Luca, A.; Cassola, G.; Vullo, V.; Carosi, G.; Antinori, A.; et al. Prevalence of hypovitaminosis D and factors associated with vitamin D deficiency and morbidity among HIV-infected patients enrolled in a large Italian cohort. J. Acquir. Immune Defic. Syndr. 2011, 58, 163-172. [CrossRef] [PubMed]

3. Dao, C.N.; Patel, P.; Overton, E.T.; Rhame, F.; Pals, S.L.; Johnson, C.; Bush, T.; Brooks, J.T. Study to Understand the Natural History of, H.I.V.; Investigators, A.i.t.E.o.E.T. Low vitamin D among HIV-infected adults: Prevalence of and risk factors for low vitamin D Levels in a cohort of HIV-infected adults and comparison to prevalence among adults in the US general population. Clin. Infect. Dis. 2011, 52, 396-405. [CrossRef] [PubMed]

4. Brown, T.T.; McComsey, G.A. Association between initiation of antiretroviral therapy with efavirenz and decreases in 25-hydroxyvitamin D. Antivir. Ther. 2010, 15, 425-429. [CrossRef] [PubMed]

5. Boura, M.; Sutre, A.F.; Badura, R.; Zagalo, A.; Afonso, C.; Caldeira, L.; Valadas, E. Hypovitaminosis D in HIV-infected patients in Lisbon: A link with antiretroviral treatment. J. Int. AIDS Soc. 2014, 17, 19826. [CrossRef] [PubMed] 
6. Conesa-Botella, A.; Florence, E.; Lynen, L.; Colebunders, R.; Menten, J.; Moreno-Reyes, R. Decrease of vitamin D concentration in patients with HIV infection on a non nucleoside reverse transcriptase inhibitor-containing regimen. AIDS Res. Ther. 2010, 7, 40. [CrossRef] [PubMed]

7. Taiwo, B.O.; Chan, E.S.; Fichtenbaum, C.J.; Ribaudo, H.; Tsibris, A.; Klingman, K.L.; Eron, J.J.; Berzins, B.; Robertson, K.; Landay, A.; et al. Less Bone Loss With Maraviroc- Versus Tenofovir-Containing Antiretroviral Therapy in the AIDS Clinical Trials Group A5303 Study. Clin. Infect. Dis. 2015, 61, 1179-1188. [CrossRef]

8. McComsey, G.A.; Kitch, D.; Daar, E.S.; Tierney, C.; Jahed, N.C.; Tebas, P.; Myers, L.; Melbourne, K.; Ha, B.; Sax, P.E. Bone mineral density and fractures in antiretroviral-naive persons randomized to receive abacavir-lamivudine or tenofovir disoproxil fumarate-emtricitabine along with efavirenz or atazanavir-ritonavir: Aids Clinical Trials Group A5224s, a substudy of ACTG A5202. J. Infect. Dis. 2011, 203, 1791-1801. [CrossRef]

9. Cozzolino, M.; Vidal, M.; Arcidiacono, M.V.; Tebas, P.; Yarasheski, K.E.; Dusso, A.S. HIV-protease inhibitors impair vitamin D bioactivation to 1,25-dihydroxyvitamin D. AIDS 2003, 17, 513-520. [CrossRef]

10. Legeai, C.; Vigouroux, C.; Souberbielle, J.C.; Bouchaud, O.; Boufassa, F.; Bastard, J.P.; Carlier, R.; Capeau, J.; Goujard, C.; Meyer, L.; et al. Associations between 25-hydroxyvitamin D and immunologic, metabolic, inflammatory markers in treatment-naive HIV-infected persons: The ANRS CO9 «COPANA cohort study. PLOS ONE 2013, 8, e74868. [CrossRef]

11. Poudel-Tandukar, K.; Poudel, K.C.; Jimba, M.; Kobayashi, J.; Johnson, C.A.; Palmer, P.H. Serum 25-hydroxyvitamin d levels and C-reactive protein in persons with human immunodeficiency virus infection. AIDS Res. Hum. Retrovir. 2013, 29, 528-534. [CrossRef] [PubMed]

12. Viard, J.P.; Souberbielle, J.C.; Kirk, O.; Reekie, J.; Knysz, B.; Losso, M.; Gatell, J.; Pedersen, C.; Bogner, J.R.; Lundgren, J.D.; et al. Vitamin D and clinical disease progression in HIV infection: Results from the EuroSIDA study. AIDS 2011, 25, 1305-1315. [CrossRef] [PubMed]

13. Aranow, C. Vitamin D and the immune system. J. Investig. Med. 2011, 59, 881-886. [CrossRef] [PubMed]

14. Holick, M.F. Vitamin D: Extraskeletal health. Rheum. Dis. Clin. North. Am. 2012, 38, 141-160. [CrossRef] [PubMed]

15. Bishop, E.; Ismailova, A.; Dimeloe, S.K.; Hewison, M.; White, J.H. Vitamin D and immune regulation: Antibacterial, antiviral, anti-inflammatory. JBMR Plus 2020. [CrossRef]

16. Aliyannissa, A.; Kuswiyanto, R.B.; Setiabudi, D.; Nataprawira, H.M.; Alam, A.; Sekarwana, N. Correlation between CD4 count and glomerular filtration rate or urine protein:Creatinine ratio in human immunodeficiency virus-infected children. Kidney Res. Clin. Pract. 2020, 39, 40-46. [CrossRef]

17. Visalli, G.; Paiardini, M.; Chirico, C.; Cervasi, B.; Curro, M.; Ferlazzo, N.; Bertuccio, M.P.; Favaloro, A.; Pellicano, G.; Sturniolo, G.; et al. Intracellular accumulation of cell cycle regulatory proteins and nucleolin re-localization are associated with pre-lethal ultrastructural lesions in circulating T lymphocytes: The HIV-induced cell cycle dysregulation revisited. Cell Cycle 2010, 9, 2130-2140. [CrossRef]

18. Espert, L.; Biard-Piechaczyk, M. Autophagy in HIV-induced T cell death. Curr. Top. Microbiol. Immunol. 2009, 335, 307-321. [CrossRef]

19. Espert, L.; Denizot, M.; Grimaldi, M.; Robert-Hebmann, V.; Gay, B.; Varbanov, M.; Codogno, P.; Biard-Piechaczyk, M. Autophagy is involved in T cell death after binding of HIV-1 envelope proteins to CXCR4. J. Clin. Investig. 2006, 116, 2161-2172. [CrossRef]

20. Nardacci, R.; Ciccosanti, F.; Marsella, C.; Ippolito, G.; Piacentini, M.; Fimia, G.M. Role of autophagy in HIV infection and pathogenesis. J. Intern. Med. 2017, 281, 422-432. [CrossRef]

21. Sassi, F.; Tamone, C.; D'Amelio, P. Vitamin D: Nutrient, Hormone, and Immunomodulator. Nutrients 2018, 10, 1656. [CrossRef] [PubMed]

22. Campbell, G.R.; Spector, S.A. Autophagy induction by vitamin D inhibits both Mycobacterium tuberculosis and human immunodeficiency virus type 1. Autophagy 2012, 8, 1523-1525. [CrossRef] [PubMed]

23. Chrobok, N.L.; Sestito, C.; Wilhelmus, M.M.; Drukarch, B.; van Dam, A.M. Is monocyte- and macrophage-derived tissue transglutaminase involved in inflammatory processes? Amino Acids 2017, 49, 441-452. [CrossRef] [PubMed]

24. Caccamo, D.; Ferlazzo, N.; Curro, M.; Ricca, S.; Ientile, R. Transglutaminase 2 Up-Regulation Is Associated with Inflammatory Response in PBMC from Healthy Subjects with Hypovitaminosis D. Med. Sci. 2018, 6, 103. [CrossRef] 
25. Sun, H.; Kaartinen, M.T. Transglutaminase activity regulates differentiation, migration and fusion of osteoclasts via affecting actin dynamics. J. Cell Physiol. 2018, 233, 7497-7513. [CrossRef]

26. Paolella, G.; Nanayakkara, M.; Sposito, S.; Lepretti, M.; Auricchio, S.; Esposito, C.; Barone, M.V.; Martucciello, S.; Caputo, I. Constitutive Differential Features of Type 2 Transglutaminase in Cells Derived from Celiac Patients and from Healthy Subjects. Int. J. Mol. Sci. 2020, 21, 1231. [CrossRef]

27. Amendola, A.; Fesus, L.; Piacentini, M.; Szondy, Z. "Tissue" transglutaminase in AIDS. J. Immunol. Methods 2002, 265, 145-159. [CrossRef]

28. Curro', M.; Ferlazzo, N.; Costanzo, M.G.; Caccamo, D.; Lentile, R. Vitamin D status influences transcriptional levels of RANKL and inflammatory biomarkers which are associated with activation of PBMC. Clin. Chim. Acta 2020, 507, 219-223. [CrossRef]

29. Mao, X.; Hu, B.; Zhou, Z.; Xing, X.; Wu, Y.; Gao, J.; He, Y.; Hu, Y.; Cheng, Q.; Gong, Q. Vitamin D levels correlate with lymphocyte subsets in elderly patients with age-related diseases. Sci. Rep. 2018, 8, 7708. [CrossRef] [PubMed]

30. Holick, M.F.; Binkley, N.C.; Bischoff-Ferrari, H.A.; Gordon, C.M.; Hanley, D.A.; Heaney, R.P.; Murad, M.H.; Weaver, C.M.; Endocrine, S. Evaluation, treatment, and prevention of vitamin D deficiency: An Endocrine Society clinical practice guideline. J. Clin. Endocrinol. Metab. 2011, 96, 1911-1930. [CrossRef] [PubMed]

31. Laplana, M.; Sanchez-de-la-Torre, M.; Puig, T.; Caruz, A.; Fibla, J. Vitamin-D pathway genes and HIV-1 disease progression in injection drug users. Gene 2014, 545, 163-169. [CrossRef] [PubMed]

32. Torres, C.; Sanchez de la Torre, M.; Garcia-Moruja, C.; Carrero, A.J.; Trujillo Mdel, M.; Fibla, J.; Caruz, A. Immunophenotype of vitamin D receptor polymorphism associated to risk of HIV-1 infection and rate of disease progression. Curr. HIV Res. 2010, 8, 487-492. [CrossRef] [PubMed]

33. Orkin, C.; Wohl, D.A.; Williams, A.; Deckx, H. Vitamin D deficiency in HIV: A shadow on long-term management? AIDS Rev. 2014, 16, 59-74. [PubMed]

34. Zicari, S.; Sessa, L.; Cotugno, N.; Ruggiero, A.; Morrocchi, E.; Concato, C.; Rocca, S.; Zangari, P.; Manno, E.C.; Palma, P. Immune Activation, Inflammation, and Non-AIDS Co-Morbidities in HIV-Infected Patients under Long-Term ART. Viruses 2019, 11, 200. [CrossRef] [PubMed]

35. Abraham, A.G.; Zhang, L.; Calkins, K.; Tin, A.; Hoofnagle, A.; Palella, F.J., Jr.; Estrella, M.M.; Jacobson, L.P.; Witt, M.D.; Kingsley, L.A.; et al. Vitamin D status and immune function reconstitution in HIV-infected men initiating therapy. AIDS 2018, 32, 1069-1076. [CrossRef]

36. Liu, N.Q.; Kaplan, A.T.; Lagishetty, V.; Ouyang, Y.B.; Ouyang, Y.; Simmons, C.F.; Equils, O.; Hewison, M. Vitamin D and the regulation of placental inflammation. J. Immunol. 2011, 186, 5968-5974. [CrossRef]

37. Shahijanian, F.; Parnell, G.P.; McKay, F.C.; Gatt, P.N.; Shojoei, M.; O'Connor, K.S.; Schibeci, S.D.; Brilot, F.; Liddle, C.; Batten, M.; et al. The CYP27B1 variant associated with an increased risk of autoimmune disease is underexpressed in tolerizing dendritic cells. Hum. Mol. Genet. 2014, 23, 1425-1434. [CrossRef]

38. Bikle, D.D.; Patzek, S.; Wang, Y. Physiologic and pathophysiologic roles of extra renal CYP27b1: Case report and review. Bone Rep. 2018, 8, 255-267. [CrossRef]

39. Trovato, M.; Ruggeri, R.M.; Sciacchitano, S.; Vicchio, T.M.; Picerno, I.; Pellicano, G.; Valenti, A.; Visalli, G. Serum interleukin-6 levels are increased in HIV-infected patients that develop autoimmune disease during long-term follow-up. Immunobiology 2018, 223, 264-268. [CrossRef]

40. Manion, M.; Hullsiek, K.H.; Wilson, E.M.P.; Rhame, F.; Kojic, E.; Gibson, D.; Hammer, J.; Patel, P.; Brooks, J.T.; Baker, J.V.; et al. Vitamin D deficiency is associated with IL-6 levels and monocyte activation in HIV-infected persons. PLOS ONE 2017, 12, e0175517. [CrossRef]

41. Shepherd, L.; Souberbielle, J.C.; Bastard, J.P.; Fellahi, S.; Capeau, J.; Reekie, J.; Reiss, P.; Blaxhult, A.; Bickel, M.; Leen, C.; et al. Prognostic value of vitamin D level for all-cause mortality, and association with inflammatory markers, in HIV-infected persons. J. Infect. Dis. 2014, 210, 234-243. [CrossRef] [PubMed]

42. Deeks, S.G. HIV infection, inflammation, immunosenescence, and aging. Annu. Rev. Med. 2011, 62, 141-155. [CrossRef] [PubMed]

43. Deeks, S.G.; Lewin, S.R.; Havlir, D.V. The end of AIDS: HIV infection as a chronic disease. Lancet 2013, 382, 1525-1533. [CrossRef]

44. Wu, S.; Sun, J. Vitamin D, vitamin D receptor, and macroautophagy in inflammation and infection. Discov. Med. 2011, 11, 325-335.

45. Wang, J.; Lian, H.; Zhao, Y.; Kauss, M.A.; Spindel, S. Vitamin D3 induces autophagy of human myeloid leukemia cells. J. Biol. Chem. 2008, 283, 25596-25605. [CrossRef] 
46. Coillard, A.; Segura, E. In vivo Differentiation of Human Monocytes. Front. Immunol. 2019, $10,1907$. [CrossRef]

47. Thomas-Ecker, S.; Lindecke, A.; Hatzmann, W.; Kaltschmidt, C.; Zanker, K.S.; Dittmar, T. Alteration in the gene expression pattern of primary monocytes after adhesion to endothelial cells. Proc. Natl. Acad. Sci. USA 2007, 104, 5539-5544. [CrossRef] 